Theatre Research in Canada

Recherches théâtrales au Canada

\title{
Roles of Theatre in Higher Education: Liberal Education and University Theatre Programs in Canada
}

\section{Glen Nichols}

Volume 39, Number 1, 2018

URI: https://id.erudit.org/iderudit/1055469ar

DOI: https://doi.org/10.7202/1055469ar

See table of contents

Publisher(s)

Graduate Centre for the Study of Drama, University of Toronto

ISSN

1196-1198 (print)

1913-9101 (digital)

Explore this journal

Cite this document

Nichols, G. (2018). Roles of Theatre in Higher Education: Liberal Education and University Theatre Programs in Canada. Theatre Research in Canada /

Recherches théâtrales au Canada, 39(1). https://doi.org/10.7202/1055469ar

All Rights Reserved (C) Theatre Research in Canada / Recherches théâtrales au Canada, 2018
This document is protected by copyright law. Use of the services of Érudit (including reproduction) is subject to its terms and conditions, which can be viewed online.

https://apropos.erudit.org/en/users/policy-on-use/ 


\title{
Roles of Theatre in Higher Education: Liberal Education and University Theatre Programs in Canada
}

\author{
GLEN NICHOLS
}

I came to the question concerning the roles that our theatre and drama programs are playing in the lives of our students through several paths. First was the language of "professional" or "pre-professional" training that seeps into so many interactions with students, university administrators, and the public. This bothered me because the thousands of theatre and drama graduates ${ }^{\mathrm{I}}$ every year are obviously not all working in the industry, so there seemed to be a disconnect between what many of our programs implicitly promise and the reality of employment. It bothered me because we often seem to speak out of both sides of our mouths, sometimes touting liberal education or liberal arts, depending on the moods at our institutions, while at other times marketing to potential students by hyping our industry star grads. It bothered me because I could find no analysis or actual research that examined any of the claims about our programs. Call this the "stick" path.

The "carrot" path was my observation that our grads from Mount Allison University, which I'm sure are no different from those from other programs (but again no research is available to test this observation), were gaining phenomenal skills as well as understandings of themselves and of the world that went well beyond the technical needs of the industry and which prepared them for highly successful careers in many fields. Inspired by this as well by examinations of these broad values of theatre and drama studies being made by our colleagues in the US, I began to wonder several things:

a. Why don't we have a more developed scholarly literature on what our programs in Canada are actually doing?

b. How might a better understanding and articulation of the values of our programs help the success of our students and of our programs in these difficult times of austerity and cutbacks?

c. What might such an understanding and articulation look like? What are the key questions such a literature should be addressing?

d. How do we go about initiating this study?

The first answer to the last question has been the organization of two modest round tables at recent CATR conferences (2016 and 2017), as a way of gauging if my questions have any resonance or if there is any interest to pursue such a study. The diversity of positions offered in both sessions has indicated the depth and variety of current thinking, and need for further research. The following papers, written by five scholars who participated in one or both of the round tables, reflect the potential conversations about how some of the ways our theatre, drama, and performance undergraduate programs are preparing students 
for life in the twenty-first century. And, more importantly, they map directions that fundamental scholarship needs to consider and why.

After Claire Carolan points out how difficult but crucial it is to unpack the list of outcomes in the "hidden curriculum" that mask the more fundamental effectiveness of our programs, Justin Blum relates a set of such hidden outcomes through a particular application: how dramaturgy, an often-overlooked area in theatre studies and metaphoric perhaps for the way theatre studies is often overlooked in our institutions, may hold a key to better understanding the roles of theatre education. In the third piece, Moira Day provides a case study of how deeper understanding of the motives of students, analysis of how program structures impact education outcomes, and linking global values of citizenship back to the practices of theatre studies not only defends the status quo against threats, but opens the doors to new connections and collaborations. Finally, Shelley Scott and James McKinnon challenge us to rethink what we do in the classroom and how we articulate our goals, in order to uncover our own practices that perpetuate the debilitations of a hidden curriculum. Especially through the latter's extensive examination of a personal case study, in which McKinnon discovered the impact of reconnecting real pedagogy to real outcomes, he unpacks the sham of traditional and unexamined classroom practices.

The common belief in the value of our programs to our students' learning comes through strongly despite the vastly different approaches resulting from different institutional histories of curriculum and practice combined with the vagaries of administrative attitudes. Most of the papers here contain lists of skills theatre students learn that are claimed to apply to the development of richer adult lives and careers. Some of these outcomes include inquiry and analysis, critical and creative thinking, integrative and reflective thinking, written and oral communication, quantitative and information literacy, intercultural understanding, teamwork, problem solving, creative thinking, invention, self-direction, flexibility, adaptability, etc. etc. That such random lists, despite their appeal, require a great deal more study is underscored by Carolan's extensive typology which sets out the complexity of trying to grapple with what these mean, how they may be promoted in our programs, and their relationship to liberal education, while Day argues in face of determined administrative arguments against liberal education that theatre and drama studies support the development of fundamental citizenship skills. And Blum argues how the study of dramaturgy develops students' capacity to navigate better the increasingly complex cultural and social trans-media world of their future.

These papers present enthusiastic illustrations of a few of the many possible scholarly approaches that could and need to be undertaken. The more fundamental premise of why they need to be undertaken, however, is pointed out by Scott and McKinnon: we are failing to communicate what any of these actually mean: to our administrators, to our students, to the general public, and perhaps even to ourselves. We have failed to communicate these because we don't actually know ourselves what they mean. When the question of what learning we are inciting is rarely asked, we have been content to rest on clichés and well-meaning, heart-warming lists of qualities: even the chestnut of "training professionals" has no consistent or comprehensive scholarship unpacking what this actually means or how it might even be measured in the university context. The beliefs rest on anecdotes and at best fragmented local applications, as these papers outline. 
It is not good enough for us just to think we know how important our programs are for educating students; we need evidence-based scholarship that demonstrates it so we can know ourselves, inform our students, and participate more fully in institutional curriculum discussions, not simply as ways to defend our little misunderstood corner against neo-liberal threats, but rather as fully articulated partners in twenty-first-century higher education.

\section{Notes}

I. Statistics Canada collects data on enrolments and graduates through the CANSIM database (Postsecondary Student Information System or PSIS). Total number of enrollments in Drama, Theatre and Stagecraft programs grew from 4,200 students 2004 to 7,230 students in 2013. The number of graduates grew from I,II3 to I,974 in the same period (Statistics Canada). These numbers count only students registered in such programs. In most cases our programs touch far more students through our courses and extracurricular theatre activities. So these numbers are very conservative.

\section{Work Cited}

Statistics Canada. "Drama/Theatre Arts and Stagecraft Enrollments and Graduates." CANSIM (database) Postsecondary Student Information System. 2016. 